\title{
Influence of foliar-applied glycinebetaine on growth, yield and some key physiological and biochemical attributes of grape (Vitis vinifera L.)
}

\section{Influência da glicinabetaína aplicada via foliar no crescimento, rendimento e alguns atributos fisiológicos e bioquímicos essenciais da uva (Vitis vinifera L.)}

\author{
Hasnain Waheed ${ }^{1 *}$; Hafiz Muhammad Tayyab Khan²; Muhammad Mansoor \\ Javaid $^{1}$; Rashad Mukhtar Balal2; Muhammad Adnan Shahid ${ }^{3}$; Mubashar Nadeem"; \\ Bilal Ahmad Khan ${ }^{1}$; Muhammad Mohsin Amin ${ }^{1}$
}

\section{Highlights}

Different levels of glycinebetaine $\mathrm{GB}(0,10,20$ and $30 \mathrm{mM})$ were applied in grapes.

All tested GB levels improved the growth and quality traits of grape.

The $\mathrm{pH}$ of grape juice was reduced by increasing GB levels.

Spray of GB at $30 \mathrm{mM}$ useful for optimum growth and quality of grapes.

\section{Abstract}

Glycinebetaine (GB) plays an imperative role to mitigate the opposing impact of several environmental stresses in various crops. The objective of this investigation was to scrutinize the response of grape (Vitis vinifera L.) to the foliar application of $\mathrm{GB}$. Diverse levels of $\mathrm{GB}(0,10,20$ and $30 \mathrm{mM})$ were applied three times with fifteen days interval to grape cv. King's Ruby. All levels of GB improved the physiological, biochemical and growth attributes of the grape. As compared to control treatment, foliar spray of GB applied at $30 \mathrm{mM}$ increased the number of leaves/vine, leaf area and number of newly emerged branches/plant by $20.55 \%$, $12.28 \%$ and $48.13 \%$, respectively. The $\mathrm{pH}$ of grape juice was decreased by increasing GB levels. However, total soluble solids, total chlorophyll contents, grape yield and photosynthesis rate was recorded maximum with foliar spray of GB applied at $30 \mathrm{mM}$. The regression model predicted that each increment in GB level enhanced the number of leaves/plant and the number of newly emerged branches/plant by 1.8 and 0.7 , respectively. Thus, it is concluded that exogenous application GB applied at $30 \mathrm{mM}$ might be more useful to

1 Resracher, Assistant Profs. Department of Agronomy, College of Agriculture, University of Sargodha, Sargodha, Pakistan. E-mail: hasnainwaheed90@yahoo.com; mmansoorjavaid@gmail.com; mubasharuaf@uaf.edu.pk; bilalahmadkhan678@gmail.com; mohsinmin123@gmail.com

2 Resracher, Assistant Profs. Department of Horticulture, College of Agriculture, University of Sargodha, Sargodha, Pakistan. E-mail: hafiztayyabkhan100@yahoo.com; uaf_rasad@yahoo.com

${ }^{3}$ Associate Prof. Department of Agriculture, Nutrition and Food Systems, University of New Hampshire, Durham, USA. E-mail:muhammad.shahid@unh.edu

* Author for correspondence

Received: Apr. 02, 2021 - Approved: June 18, 2021 
obtain the optimum growth and quality of grapes.

Key words: Chlorophyll contents. Leaf area. Foliar spray. Photosynthesis. Total soluble salts.

\section{Resumo}

A glicina betaína (GB) desempenha um papel fundamental para mitigar o impacto oposto de vários estresses ambientais em várias culturas agrícolas. $O$ objetivo desta pesquisa foi examinar a resposta da uva (Vitis vinifera L.) à aplicação foliar de GB. Diversos níveis de GB (0, 10, 20 e 30 mM) foram aplicados três vezes com intervalo de 15 dias à videira cv. King's Ruby. Todos os níveis de GB melhoraram os atributos fisiológicos, bioquímicos e de crescimento da uva. Em comparação ao tratamento controle, a pulverização foliar de GB aplicada à $30 \mathrm{mM}$ aumentou o número de folhas / videira, área foliar e número de ramos / planta recém-emergidos em $20,55 \%, 12,28 \%$ e $48,13 \%$, respectivamente. $\mathrm{O}$ pH do suco de uva diminuiu com o aumento dos níveis de GB. No entanto, sólidos solúveis totais, conteúdo de clorofila total, rendimento de uva e taxa de fotossíntese foram registrados no máximo com pulverização foliar de GB aplicada a $30 \mathrm{mM}$. O modelo de regressão previu que cada incremento no nível de GB aumentava o número de folhas / planta e o número de ramos / planta recém-emergidos em 1,8 e 0,7, respectivamente. Assim, conclui-se que a aplicação exógena GB aplicada `30 mM pode ser mais útil para obter o crescimento e a qualidade ideais das uvas.

Palavras-chave: Teores de clorofila. Área foliar. Pulverização foliar. Fotossíntese. Sais solúveis totais.

\section{Introduction}

In the word, grapes (Vitis vinifera L.) belongs to the major fruit crops and it is recognized as one of the best economically imperative fruit crops in temperate and subtropical regions. However, it is frequently grown in the areas where ecological stress may reduce its productivity or fruit quality (Mickelbart, Chapman, \& Collier-Christian, 2006). The experimental site is situated in the temperate zone with steppe, dry and grassy plains characteristics (Rehman et al., 2018). Numerous environmental factors such as salinity, extreme temperature, drought and nutrient imbalances are the major stresses to crop proficiency (Ashraf \& Foolad, 2007). Many approaches to reduce the environmental stresses among these use of osmoprotectant is one of the most viable strategies (Ashraf \& Foolad, 2007).
Glycinebetaine (GB) is an osmoprotectant and most abundant quaternary ammonium compound (QAC) that protects the plant from several environmental stresses (Yang, Rich, Aztell, Wood, \& Bonham, 2003). In accumulation to its purpose in osmoregulation (Farooq et al., 2008), GB is also operative in protecting the numerous efficient proteins, dynamic enzymes (e.g. Rubisco) and photosynthetic apparatus (Farooq, Wahid, Ito, Lee, \& Siddique, 2009) and improving the crop productivity (Hussain, Malik, Farooq, Ashraf, \& Cheema, 2008). Foliar application of GB is easy to apply, inexpensive and non-toxic to the plants and environment (Duman, Aksoy, Aydin, \& Temizgul, 2011). Exogenously applied GB enhanced the tolerance in plants against stress (Mickelbart et al., 2006). Biosynthesis and addition of harmonious osmolytes with lower molecular weight in plants is one of the utmost operative mechanism to maintain 
cellular integrity under multiple abiotic stresses (Kumar et al., 2017) and GB and N-trimethyl derivative of glycine are most efficient and compatible osmolytes that mitigate the biotic stress in plants. GB induction in specific genes (codA for Arabidopsis thaliana, Brassicajuncea and Oryza sativa; cox for B. napus, Nicotiana tabacum) whose produces are engaged in stress tolerance and GB prevent the gathering of surplus reactive oxygen species, thus protecting the photosynthesis mechanism from the collective impacts of light strain and other stressors as well as ion channel proteins and cell membrane reliability (Chen \& Murata, 2008). Accumulation of lower GB concentrations in plants and its use as foliar spray is a promising approach to mitigate the adversative effects imposed by various abiotic factors (Chen \& Murata, 2008). Foliar GB spray is taken up by the leaves and transported to different organs, thus enhancing the tolerance of several plant species to different types of abiotic stresses (Habib, Ashraf, Ali, \& Perveen, 2012) and increasing the successive growth, productivity and quality (Mahouachi, Argamasilla, \& Gómez-Cadenas, 2012; Cuin \& Shabala, 2007). The GB is eagerly engrossed by the leaf tissues when applied to plant leaves (Park, Jeknic, \& Chen, 2006). Chronic salt or water stress caused distinct changes in protein expression but these changes were more in pericarp proteins compared to seed proteins. Under water stress conditions, skin of graps indicated the profusion of volatile oxygen purification enzymes, pulp showed enhanced methionine synthase, PR proteins and glutamate decarboxylase (Grimplet et al., 2009). GB foliar application was the proposed and operative method to make tolerance in plants against stress situations with low solute addition (Bhatti et al., 2013). In particular, the level of GB, species type and the period applied were the main dynamics that determined the efficiency of foliar GB spray (Ashraf \& Foolad, 2007).

It is imperative to use an appropriate level of GB to decrease the adverse effect of environmental stresses and help to increase the production and quality of fruits. In general, the role of GB applied in vindicating the opposing corollaries of environmental stresses has been informed in numerous studies but, diminutive is identified about the effects of this growth regulator on grapes. Moreover, grapes cv. King's Ruby was selected in the experiment which is widely cultivated and most responsive to stress conditions (Khan, 2019). Thus, the current study was performed: (i) to scrutinize the GB uptake in grape leaves and its impacts on physiology and growth and (ii) to find out the optimum level of GB for maximum growth and quality of the grape.

\section{Material and Methods}

\section{Site and soil properties}

The experiments were initiated at the College of Agriculture, University of Sargodha (32.0 ${ }^{\circ} \mathrm{N}$ and $72.6^{\circ} \mathrm{E}$ ) Pakistan, from March to May 2016 and 2017. The experimental site has annual rainfall of $526 \mathrm{~mm}$, average summer and winter temperatures ranging from 25 to $49^{\circ} \mathrm{C}$ and 5 to $23^{\circ} \mathrm{C}$ respectively (Khan, 2019). Grape cv. King's Ruby (Vitis vinifera L.) was used as the experimental material. 'Kings Ruby' was selected based on the report of Rehman et al. (2018) as it is a widely cultivated seedless and early maturing cultivar in Pakistan with excellent taste, attractive red color, large size berries. Samples of soil were accumulates at planting time from a depth of 0-10, 10-20 and $20-30 \mathrm{~cm}$. From each replicate the numerous 
subsamples were collected then bulked to one sample in every replicate and depth. The soil analysis of the experimental site was indicated in Table 1. Soil pH and organic matter ranged between 7.10 to 7.62 and 1.01 to $1.29 \%$, respectively, at 0 to $30 \mathrm{~cm}$ depth. However, the level of $\mathrm{N}, \mathrm{P}$ and $\mathrm{K}$ was low to medium at experimental site (Table 1).

Table 1

Soil analysis of the experimental site

\begin{tabular}{ccccc}
\hline & \multicolumn{4}{c}{ Soil sample depth $(\mathrm{cm})$} \\
\cline { 2 - 5 } Characteristic & $0-10$ & $10-20$ & $20-30$ & Mean \\
\hline Soil pH & 7.10 & 7.18 & 7.62 & 7.3 \\
Organic Matter (\%) & 1.29 & 1.15 & 1.01 & 1.15 \\
\hline Total Nitrogen (\%) & 0.065 & 0.062 & 0.056 & 0.061 \\
Olsen's P $\left(\mathrm{mg} \mathrm{kg}^{-1}\right)$ & 5.16 & 7.01 & 9.95 & 7.37 \\
Extractable K $\left(\mathrm{mg} \mathrm{kg}^{-1}\right)$ & 172 & 161 & 116 & 149.6
\end{tabular}

\section{Experimental design and treatments}

The experiments were laid out in Randomized Complete Block Design and replicated three times. There are four levels of GB including: no application of $G B$, foliar GB spray at $10 \mathrm{mM}$, foliar GB spray at $20 \mathrm{mM}$, foliar GB spray at $30 \mathrm{mM}$. Foliar GB spray were applied three times (before flowering, at flowering and at fruit making stage) with fifteen days interval on all above ground biomass of the plants. The age of the selected plants from vineyard for foliar spray was two years. The square planting system was used with $1.5 \mathrm{~m}$ of row to row as well as plant to plant distance. For foliar spray of GB Knapsack sprayer was used and the plant samples were taken after the GB sprayed then the collected plant samples are inspect for different biochemical, physiological and growth parameters.

\section{Data collection}

After 10 days of the last GB spray, the number of leaves per plant and number of newly emerged branches were estimated manually. The leaf area meter (Model MK2, DT Area Meter, Delta. T Devices, Cambridge, United Kingdom) was used to measured the leaf area three times after 10 days of every spray and then their average was worked out (O'Neal, Landis, \& Isaacs, 2002). An ATAGO RS5000 refractometer (Atago, Japan) was used to calculate the total soluble solids (TSS) of the grape juice. The TSS reading (\%) was observed using a refractometer barbed directly at the source of light (Saleem, Malik, \& Farooq, 2007). To measure the $\mathrm{pH}$, approximately grape juice of $20 \mathrm{ml}$ was placed in a beaker and the $\mathrm{pH}$ was determined with digital $\mathrm{pH}$ meter (Cairns, Watson, Creanor, \& Foye, 2002). The total chlorophyll contents in the leaf were recorded according to the technique of Arnon (1949). For recorded the grape yield $\left(\mathrm{kg} \mathrm{plant}^{-1}\right)$, 
the berry sampling of about ten clusters, demonstrating five vines of each replicate, was used at maturity. Net photosynthesis rate, transpiration rate and stomatal conductance were recorded using a portable infrared gas analyzer (Cl-340 Photosynthesis System [Portable], CID Bio-sciences, USA) with the following modifications: The system was configured for an open system with atmospheric pressure of $99.5 \mathrm{kPa}$, a mass flow rate of $0.33 \mathrm{~mol} \mathrm{~m}^{-2} \mathrm{~s}^{-1}$, the optical photon flux density was set at 1000-1393 $\mu \mathrm{mol} \mathrm{m} \mathrm{m}^{-2}$ $\mathrm{s}^{-1}$ obtained from ambient light. The vapor pressure of water at the leaf chamber outlet ranged from 1.7 to $2.4 \mathrm{kPa}$, the ambient air temperature was 23 to $34^{\circ} \mathrm{C}$ in the leaf slot. Quantities were calculated between 10:30 am and 12:30 pm and the leaves which are fully extended were selected for measurements under ambient $\mathrm{CO}_{2}$ concentration (Long \& Bernacchi, 2003). Data regarding the number of leaves per plant, number of newly emerged branches/plant and net photosynthesis rate against $\mathrm{GB}$ levels was interpreted according to linear regression.

\section{Statistical Analysis}

Data of both years was non-significant and the data were pooled over the year. The recorded data were scrutinized statistically by using Statistix 8.1 software and analysis of variances (ANOVA) technique and significant of treatments means were compared by using Least Significant Difference Test (LSD) at $5 \%$ probability level (Steel, Torrie, \& Dickey, 1997). The regression analysis and figures were drawn by using Sigma Plot 2008 (Version 11.0 ) by using standard error ( \pm SE). Average of the both year's data was presented for each parameter.

\section{Results and Discussion}

The impact of foliar GB spray on the number of leaves/plant, leaf area and the number of newly emerged branches/plant are shown in Figures 1,2 and 3 respectively. Data exhibited that application of all GB levels markedly enhanced the number of leaves/plant of grapes however the application of $30 \mathrm{mM} \mathrm{GB}$ significantly improved the number of leaves/ plant (261.3) as compared to control treatment (0 mM) (Figure 1). From the regression model, it is estimated that each increment in GB (mM) level increased the number of leaves/plant by 1.8 (Figure 4). The leaf area also showed significant differences as compared to nonGB treatment (Figure 2). However, the highest leaf area $\left(272.8 \mathrm{~cm}^{2}\right)$ was observed with 30 $\mathrm{mM}$ of GB spray. In case of the number of newly emerged branches, foliar spray of all GB levels improved the number of branches and the treatments were ranked as follows: $30 \mathrm{mM}>20 \mathrm{mM}>10 \mathrm{mM}>0 \mathrm{mM}$. However, the number of newly emerged branches with 10,20 and $30 \mathrm{mM}$ were enhanced significantly by $31(20.55 \%), 36(21.06 \%)$ and $43(48.13 \%)$, respectively as compared to non-GB treatment (Figure 3). The regression equations predicted that each increment in GB level ( $\mathrm{mM}$ ) increased the number of newly emerged branches per plant by 0.7 in grapes (Figure 5). The outcomes of this investigation designated that among all the tested levels of $\mathrm{GB}$, application of $30 \mathrm{mM}$ GB is the most appropriate level and GB foliar spray significantly improved the number of leaves/plant that might have been due to foliar spray of GB which play a dynamic role in the physiological function of plant and increased the number of leaves. Analogous results were stated by Rezaei, Jokar, Ghorbanli, Kaviani and Kharabian-Masouleh (2012) who established that foliar spray of GB increased the number 
of leaves/plant in tomato at different concentrations. According to Ashraf and Foolad (2007) when different concentrations of GB were applied to higher plant it had increased the number of leaves. Overall leaf investigations were revealed that foliar GB spray led to remarkable enhancement in the leaf area of the grape, as already stated by Shahbaz, Masood, Perveen and Ashraf (2012) who reported a stimulating effect of $\mathrm{GB}$ on leaf area of wheat. Our results showed that the number of newly emerged branches/plant increased might be due to GB application that reduced the opposing impact of several abiotic factors and increased plant growth and development. Several other scientists have also been reported that GB shown positive impacts on the growth and progress of many plants grown under stressful circumstances (Bharwana et al., 2014). External application of GB has enhanced the tolerance of many plant species to different types of abiotic stresses and may increase the subsequent growth and production (Chen \& Murata, 2008).

A significant reduction in total soluble solid (\%) was observed with no-GB treatment than all other levels of GB. Data in figure 6 also suggested that higher levels of GB (20 and $30 \mathrm{mM}$ ) produced non-significant results for total soluble solids. However, among all the treatments foliar application of 20 $\mathrm{mM} \mathrm{GB}$ recorded the highest value of total soluble solid (13.50\%). GB applied as foliar spray has been reported to be absorbed by leaves and transported to different organs, thus improving the tolerance of many plant species to various types of environmental stresses (Habib et al., 2012) and promoting the succeeding growth and productivity and quality (Mahouachi et al., 2012; Cuin \& Shabala, 2007). Environmental stresses decreased the chlorophyll concentration which eventually affects the growth, productivity and quality of produce (Manivannan, Rabert, Rajasekar, \& Somasundaram, 2015). Similarly, Mickelbart et al. (2006) also described that the application of GB also augmented the growth and quality of grapes.

The $\mathrm{pH}$ of grape juice varied significantly with each other due to foliar spray of different GB levels (Figure 7). The grape plants that were not treated with GB $(0$ $\mathrm{mM}$ ) recorded the highest $\mathrm{pH}$ of juice (3.62) while the GB-treated plants were produced reasonably lower values. However, data also indicated that 20 or $10 \mathrm{mM} \mathrm{GB}$ statistically at par with each other in terms of juice $\mathrm{pH}$. While, the lowest value of $\mathrm{pH}$ of grape juice (3.23) was perceived from the plants that were treated with foliar spray of GB at $30 \mathrm{mM}$ (Figure 7). A significant decrease in the $\mathrm{pH}$ of grape juice was observed by enhancing the GB concentration that may be due to optimum level of GB that reduce the opposing impact of abiotic stresses. The foliar application of other stress preventing compound i.e. abscisic acid that regulates the dormancy as well as improved the ripening, berry color and quality of grape (Zhang, Mechlin, \& Dami, 2011). In another study, Ferrandino and Lovisolo (2013) also indicated that foliar spray of abscisic acid to grapevine showed as an effective method to enhance grape quality by controlling abiotic stress.

The total chlorophyll contents of grape plants were enhanced significantly with increasing GB levels from 0 to $30 \mathrm{mM}$. Data in figure 8 indicated that foliar application of $\mathrm{GB}$ at 30, 20 and $10 \mathrm{mM}$ increased the total chlorophyll contents by $43.24 \%\left(3.7 \mathrm{mg} \mathrm{g}^{-1}\right)$, $32.25 \%\left(3.1 \mathrm{mg} \mathrm{g}^{-1}\right)$ and $19.23 \%\left(2.6 \mathrm{mg} \mathrm{g}^{-1}\right)$, respectively as compared to non-GB treated 
plants (0 mM). In our findings total chlorophyll contents were improved with foliar spray of GB may be due to reducing the opposing consequences of environmental pressures and enhancing the total chlorophyll contents. There is confirmation that GB acts to enhance the chlorophyll concentration (Blunden, Jenkins, \& Liu, 1996) or to defend against its degradation under abiotic stress conditions (Gadallah, 1999). In another study, it was reported that enhancement in chlorophyll contents was more in canola crop at higher concentration of foliar-applied plant growthpromoting substances (Athar, Zafar, \& Ashraf, 2015) and the authors also reported that the enhanced photosynthesis in plants sprayed with plant growth-promoting substances was connected with increased in stomatal conductance and chlorophyll contents.

In terms of grape yield, foliar spray of $30 \mathrm{mM}$ GB produced a significantly higher yield than those with 10, 20 and $0 \mathrm{mM}$ GB (Figure 9). While, foliar spray of GB at 10 and $20 \mathrm{mM}$ were recorded statistically similar yield but it was significantly higher than that of noGB treatment. It is indicated that the foliar spray of GB positively influenced the grape yield (Figure 9). The enhancement in the grape yield might have been due to the foliar spray of GB that improved the chlorophyll contents in the plants. Similar, results are also indicated by Blunden et al. (1996) who revealed that chlorophyll contents in leaves were improved due to the presence of betaines in seawood. Many researchers are indicating the positive impact of foliar GB spray on plant growth and yield in various crops i.e. papaya, tobacco, common beans (Phaseolus vulgaris L.) and soybean (Glycine max L.) (Agboma, PeltonenSainio, Hinkkanen, \& Pehu, 1997; Ashraf \& Foolad, 2007; Mahouachi et al., 2012).
Net photosynthesis rate of grape plants were increased linearly with an increase in $\mathrm{GB}$ levels $(0,10,20$ and $30 \mathrm{mM}$ ) (Figure 10). Among all the applied GB levels, the highest net photosynthesis rate $(15.1 \mathrm{mmol}$ $\mathrm{m}^{-2} \mathrm{~s}^{-1}$ ) of grape plants were observed with foliar spray of $30 \mathrm{mM} \mathrm{GB}$ which was followed by 20 and $10 \mathrm{mM}$ GB application. The least net photosynthesis rate of grape plants was perceived where no-GB treatment was applied (Figure 10). In contrast, the transpiration rate of grape plants was showed a different pattern than that of the net photosynthesis rate (Figure 11). As compared to control treatment, foliar application of $30 \mathrm{mM} \mathrm{GB}$ produced maximum transpiration rate $\left(3.6 \mathrm{mmol} \mathrm{m} \mathrm{m}^{-2} \mathrm{~s}^{-1}\right)$ of grape plants which was followed by foliar spray of GB applied at $10 \mathrm{mM}$ (Figure 11). A significant reduction in stomatal conductance of grape plants was observed with no-GB treatment. However, the foliar spray of $20 \mathrm{mM}$ GB proved to be the best and produced the highest stomatal conductance $\left(283.5 \mathrm{mmol} \mathrm{m}^{-2} \mathrm{~s}^{-1}\right)$ of grape plants (Figure 12).

In our study net photosynthesis rate was increased with exogenous application of GB applied at $30 \mathrm{mM}$ might be due to enhanced in chlorophyll contents. Generally, it is closely related to total leaf chlorophyll contents and broadly used to assess the common state of photosynthetic device (Pireivatlou, Aliyev, Hajieva, Javadova, \& Akparov, 2008). It is documented that higher contents of chlorophyll were associated with improved yield (Li, Guo, Michael, Stefania, \& Salvatore, 2006). The enhancement in stomatal conductance under foliar GB spray might be due to the accumulation of GB in specific cells or cellular compartments with consequences for stomatal functions. These outcomes are related to the consequences of Mäkelä, Munns, 
Colmer, Condon, \& Peltonen-Sainio (1998) who stated that tomato (Lycopersicon esculentum Mill.) species is unable to synthesis GB and foliar application of GB expressively augmented the stomatal conductance of tomato grown under water or drought situations (Sorwong \& Sakhonwasee, 2015). Furthermore, the higher transpiration rate and stomatal conductance in GB-treated plants may also support heat dissipation from leaves and improve the photosynthetic machinery. Foliar spray of GB significantly improves the photosynthesis, transpiration rate and stomatal conductance (Shahbaz et al., 2012). GB treatment was found to increase the stomatal conductance under stress or normal condition. Thus this higher value of photosynthetic rate or transpiration rate could be attributed to the effect of GB on stomatal conductance. The findings regarding
GB enhancement in chlorophyll contents, photosynthesis, yield and its related attributes due to foliar-applied osmoprotectant are in agreement with various reports (Arfan, Athar, \& Ashraf, 2007; Li et al., 2006; Malik \& Ashraf, 2012). Stress conditions have a major impact on protein expression profile in grape pericarp, skin and pulp tissues. Numerous reports showed that exogenous GB application augmented the tolerance to diverse abiotic strains and reduced the change in protein expressions due to stress conditions (Chen \& Murata, 2011; Giri, 2011). For example, foliar-applied GB to strawberry increased the freezing tolerance from -5.9 to $-10.8^{\circ} \mathrm{C}$ (Adak, 2019). Similarly, exogenous GB application increased the cold tolerance in grapevine (Mickelbart et al., 2006) and tomato seedlings (Park et al., 2006).

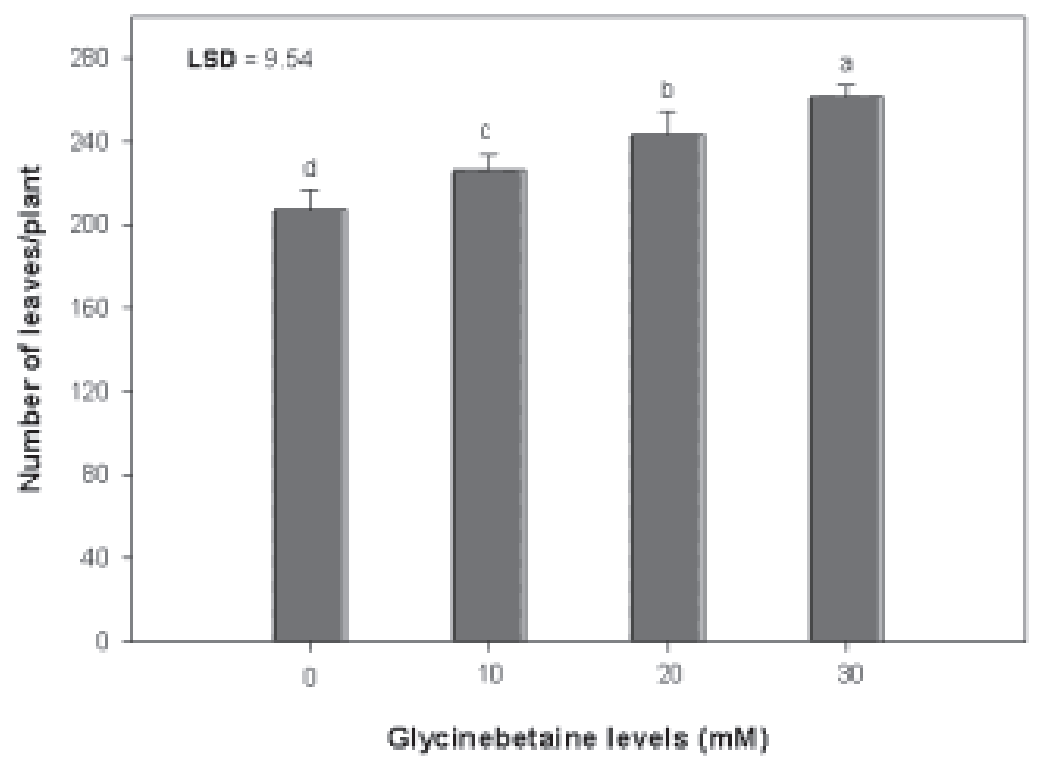

Figure 1. Impact of foliar-applied glycinebetaine (GB) on number of leaves per plant of grape (cv. King's Ruby). Spikes on the perpendicular bars symbolize the standard error of the means. 


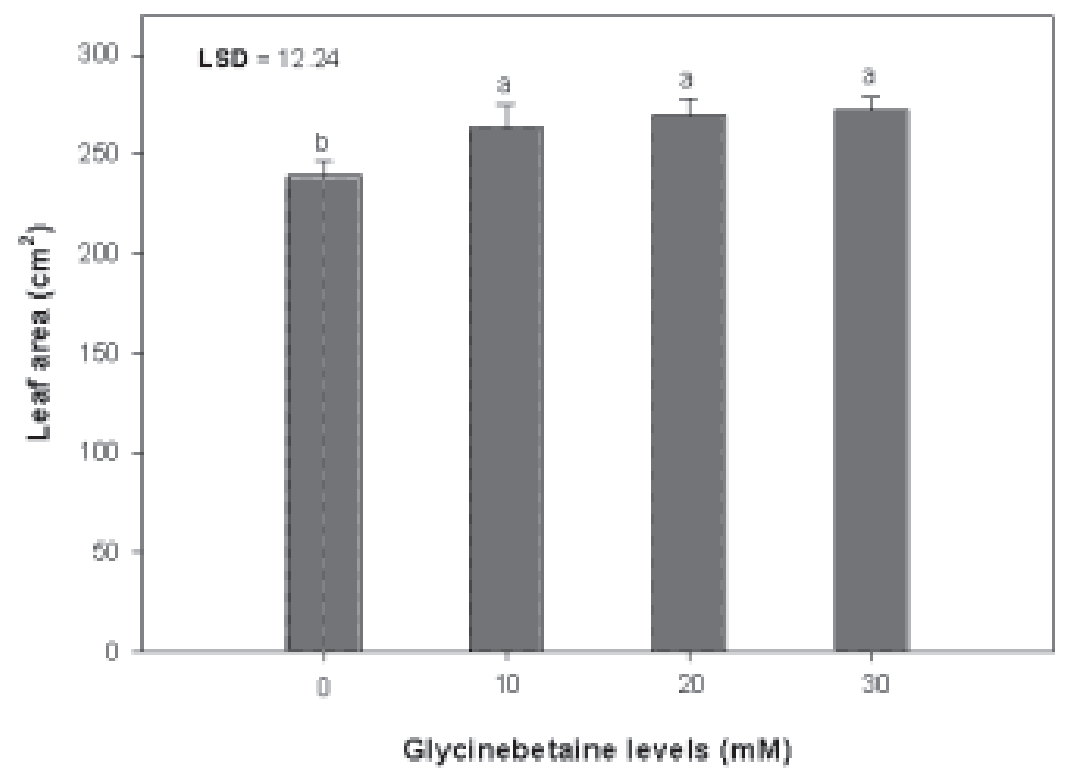

Figure 2. Impact of foliar-applied glycinebetaine (GB) on leaf area ( $\left.\mathrm{cm}^{2}\right)$ of grape (cv. King's Ruby). Spikes on the perpendicular bars symbolize the standard error of the means.

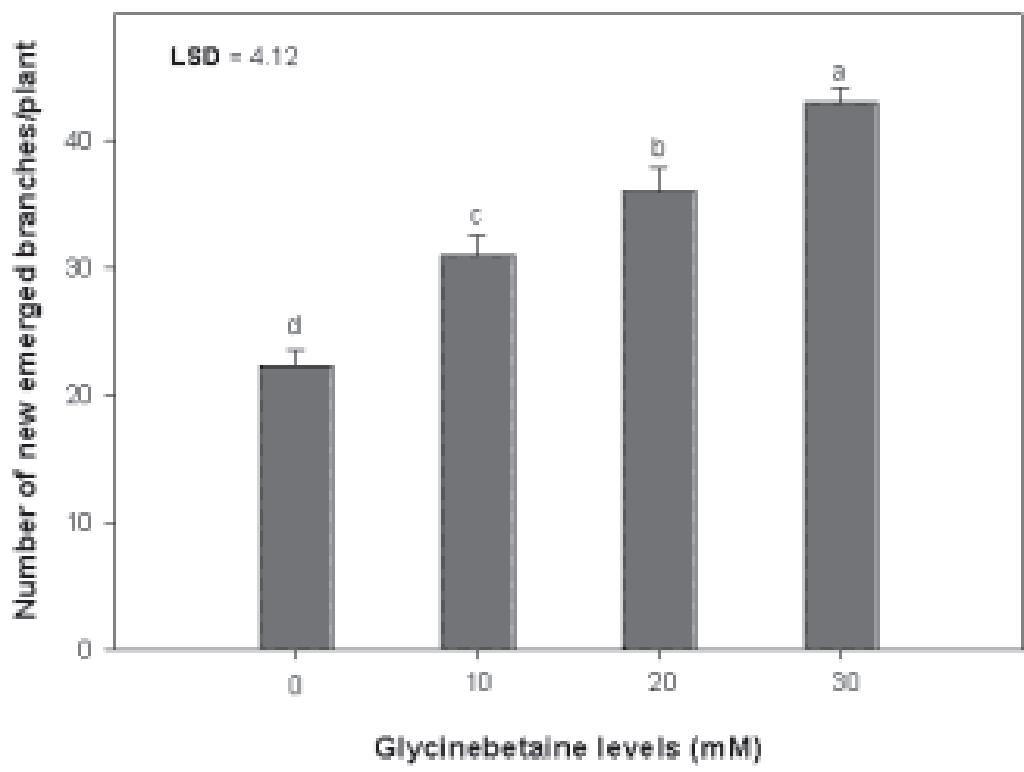

Figure 3. Impact of foliar-applied glycinebetaine (GB) on number of new emerged branches per plant of grape (cv. King's Ruby). Spikes on the perpendicular bars symbolize the standard error of the means. 


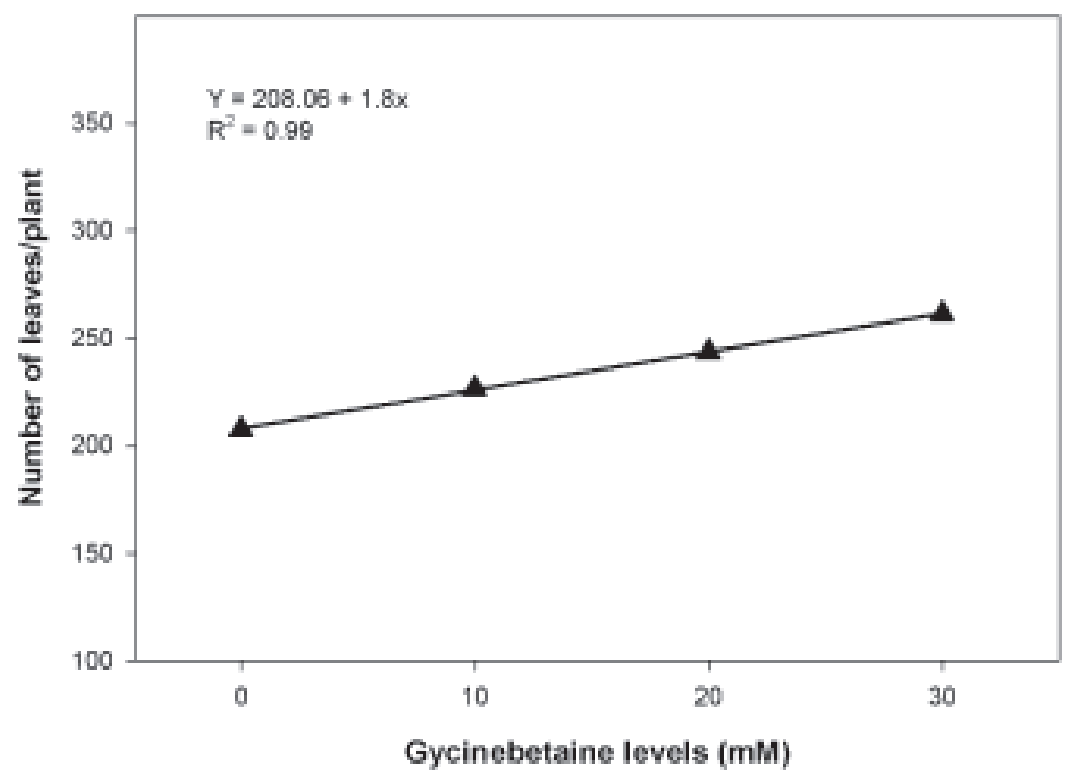

Figure 4. Regression analysis for number of leaves per plant of grape (cv. King's Ruby) as influenced by different glycinebetaine (GB) levels.

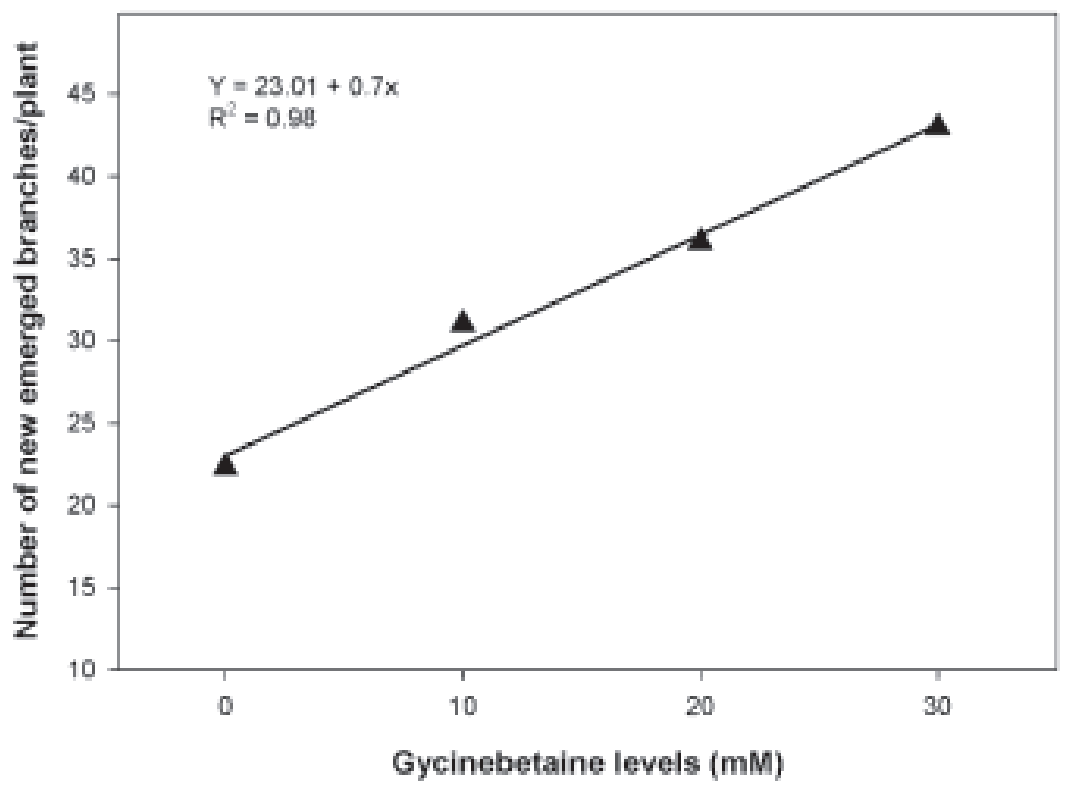

Figure 5. Regression analysis for number of new emerged branches per plant of grape (cv. King's Ruby) as influenced by different glycinebetaine (GB) levels. 


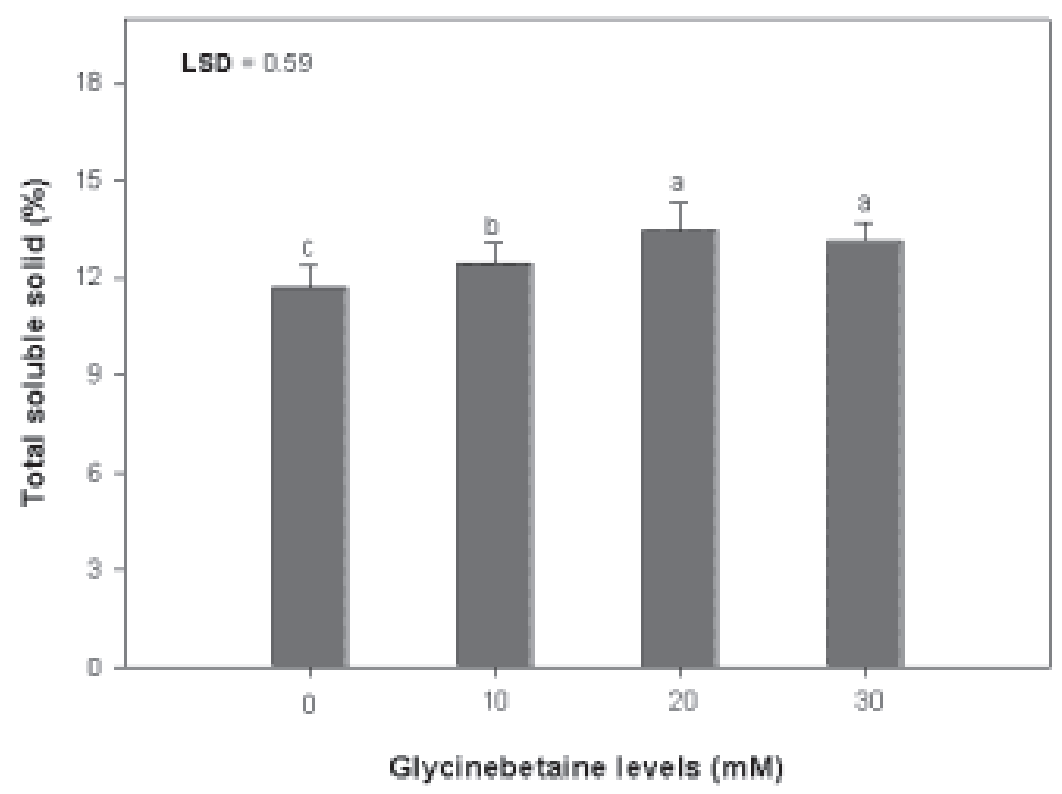

Figure 6. Impact of foliar-applied glycinebetaine (GB) on total soluble solid (\%) of grape (cv. King's Ruby). Spikes on the perpendicular bars symbolize the standard error of the means.

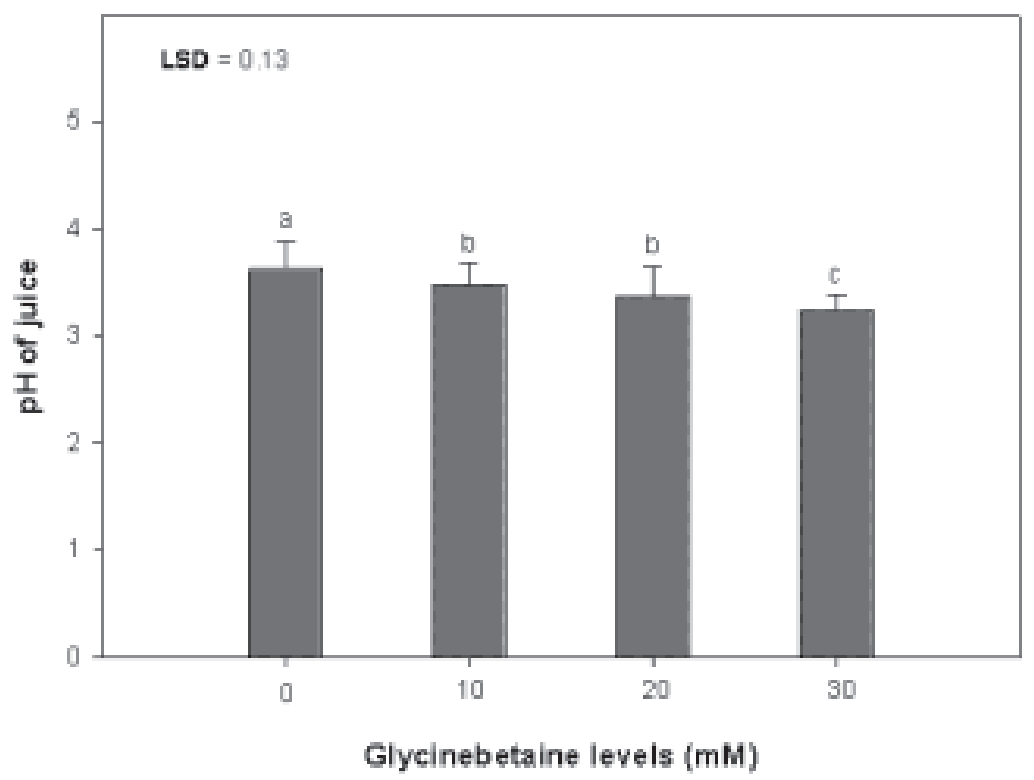

Figure 7. Impact of foliar-applied glycinebetaine (GB) on pH of grape (cv. King's Ruby). Spikes on the perpendicular bars symbolize the standard error of the means. 


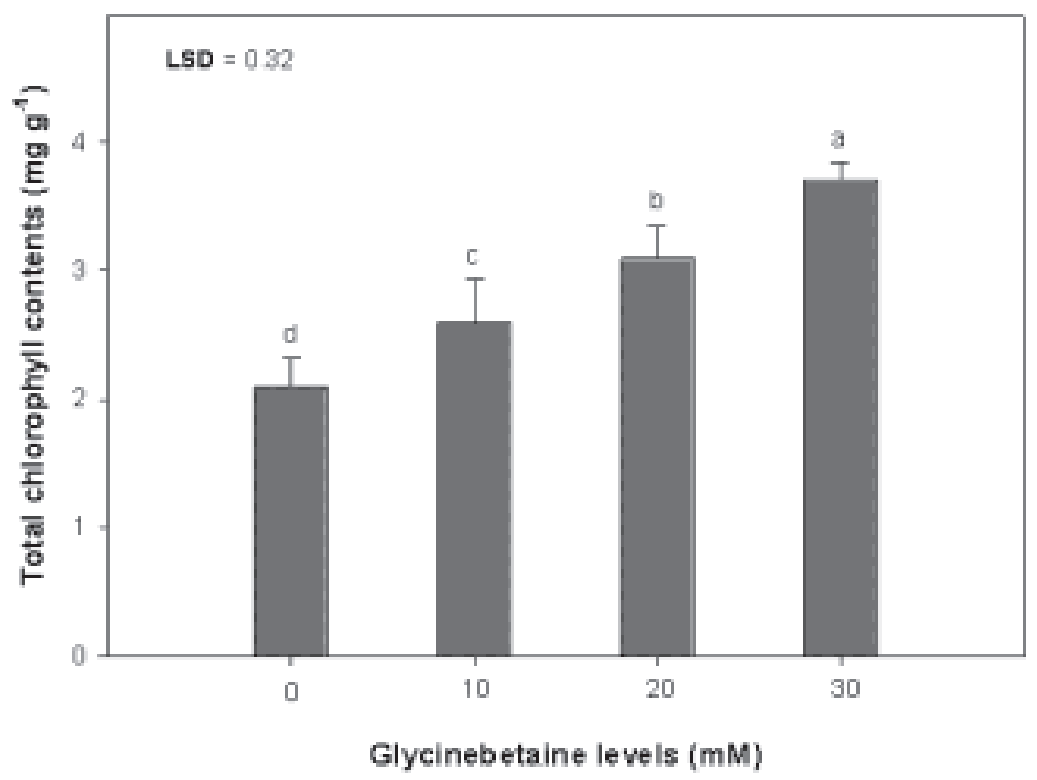

Figure 8. Impact of foliar-applied glycinebetaine (GB) on total chlorophyll contents $\left(\mathrm{mg} \mathrm{g}^{-1}\right)$ of grape (cv. King's Ruby). Spikes on the perpendicular bars symbolize the standard error of the means.

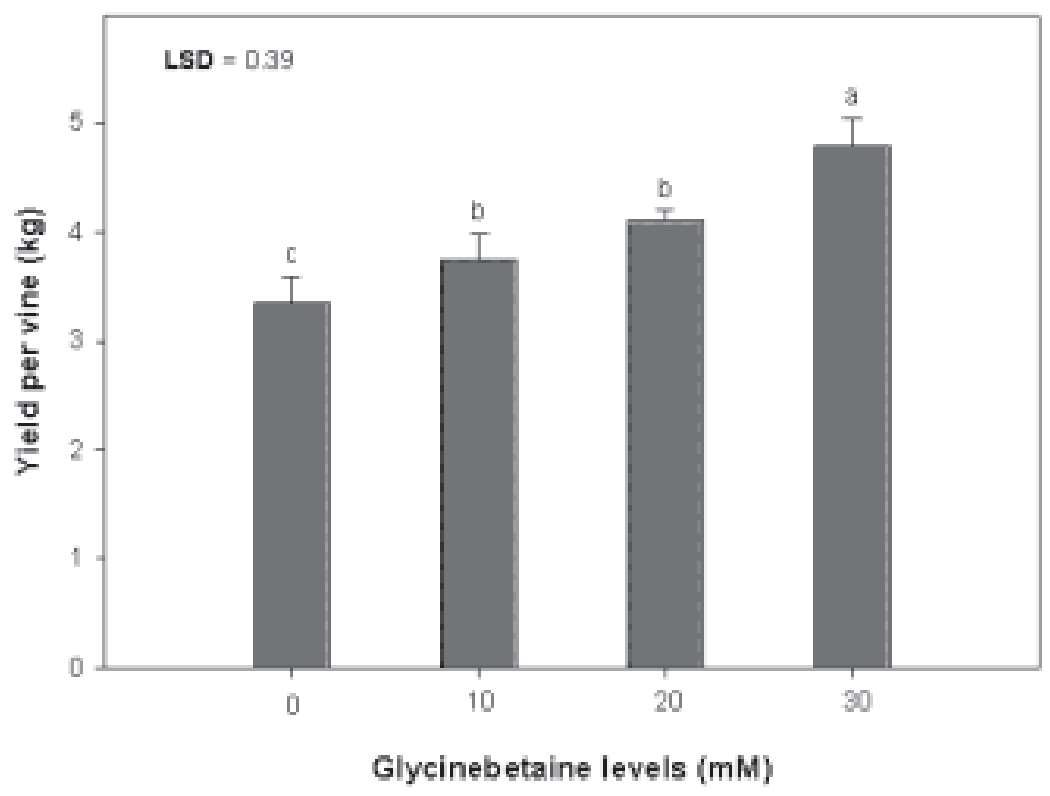

Figure 9. Impact of foliar-applied glycinebetaine (GB) on yield per vine (kg) of grape (cv. King's Ruby). Spikes on the perpendicular bars symbolize the standard error of the means. 


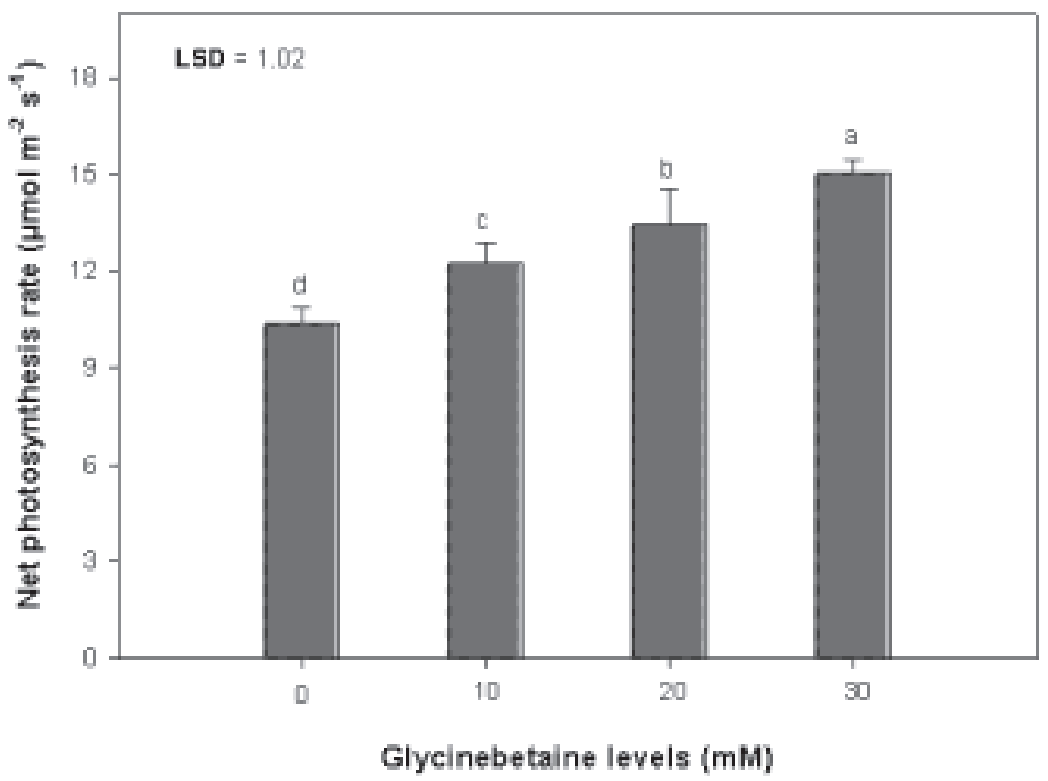

Figure 10. Impact of foliar-applied glycinebetaine (GB) on net photosynthesis rate $\left(\mu \mathrm{mol} \mathrm{m} \mathrm{m}^{-2} \mathrm{~s}^{-1}\right)$ of grape (cv. King's Ruby). Spikes on the perpendicular bars symbolize the standard error of the means.

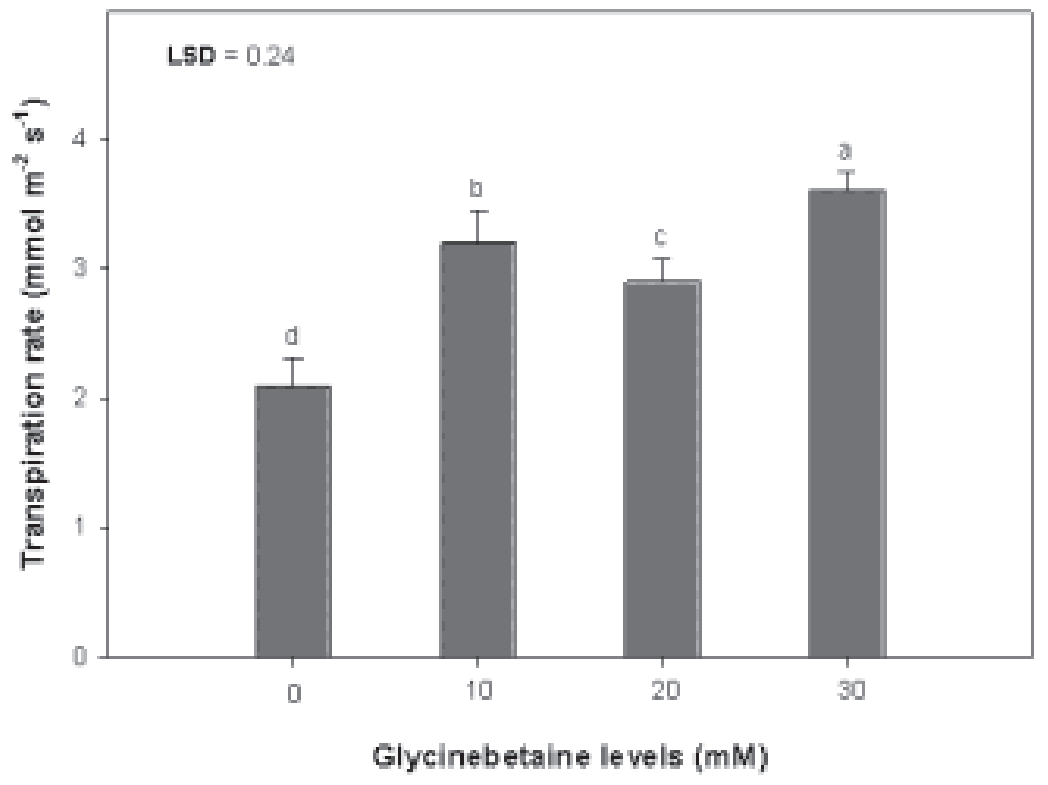

Figure 11. Impact of foliar-applied glycinebetaine (GB) on transpiration rate $\left(\mathrm{mmol} \mathrm{m}^{-2} \mathrm{~s}^{-1}\right)$ of grape (cv. King's Ruby). Spikes on the perpendicular bars symbolize the standard error of the means. 


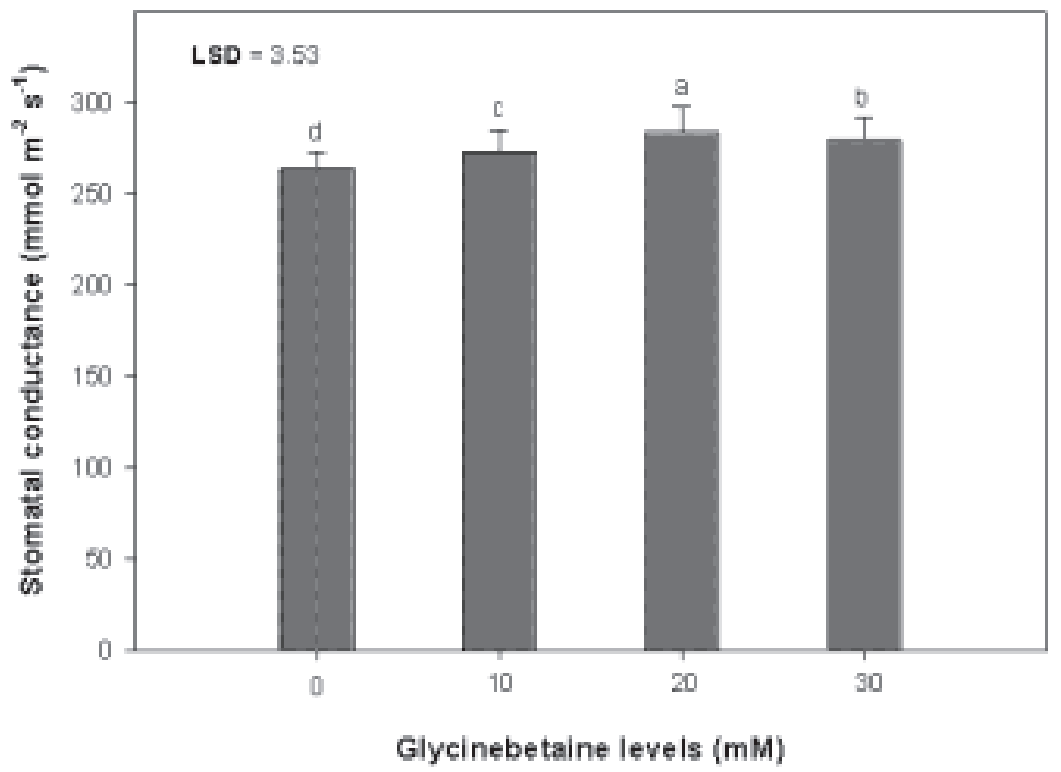

Figure 12. Impact of foliar-applied glycinebetaine (GB) on stomatal conductance (mmol m-2 s-1) of grape (cv. King's Ruby). Spikes on the perpendicular bars symbolize the standard error of the means.

\section{Conclusion}

Foliar spray of GB has been found to enhance the biochemical, physiological and growth response of grape. An increase in GB level from 0 to $30 \mathrm{mM}$ significantly improved the number of leaves/plant, total soluble solids, total chlorophyll contents, grape yield and net photosynthesis rate. However, a reduction in the $\mathrm{pH}$ of grape juice was observed by increasing GB levels. Thus, the study concluded that among all the concentrations, foliar spray of GB if applied at $30 \mathrm{mM}$ is more useful to obtain the optimum growth and quality of grapes. However, the threshold level of the foliar-applied GB should be estimated in future research.

\section{References}

Adak, N. (2019). Effects of glycine betaine concentrations on the agronomic characteristics of strawberry grown under deficit irrigation conditions. Applied Ecology and Environmental Research, 17(2), 3753-3767. doi: 10.15666/aeer/17 $02 \_37533767$

Agboma, P., Peltonen-Sainio, P., Hinkkanen, R., \& Pehu, E. (1997). Effect of foliar application of glycine betaine on yield components of drought stressed tobacco plants. Experimental Agriculture, 33(3), 345-352. doi: $10.1017 / S 0014479797003062$

Arfan, M., Athar, H. R., \& Ashraf, M. (2007). Does exogenous application of salicylic acid through the rooting medium modulate growth and photosynthetic capacity in two differently adapted spring wheat 
cultivars under salt stress? Journal of Plant Physiology, 164(6), 685-694. doi: 10.1016/j.jplph.2006.05.010

Arnon, D. I. (1949). Copper enzymes in isolated chloroplasts. Polyphenoloxidase in Beta vulgaris. Plant Physiology, 24(1), 1-15. doi: 10.1104/pp.24.1.1

Ashraf, M., \&Foolad, M. R. (2007). Roles of glycine betaine and proline in improving plant abiotic stress resistance. Environmental and Experimental Botany, 59(2), 206-216. doi: 10.1016/j.envexpbot.2005.12.006

Athar, H., Zafar, Z., \& Ashraf, M. (2015). Glycinebetaine improved photosynthesis in canola under salt stress: evaluation of chlorophyll fluorescence parameters as potential indicators. Journal of Agronomy and Crop Science, 201(6), 428-442. doi: 10.1111/jac. 12120

Bharwana, S. A., Ali, S., Farooq, M. A., lqbal, N., Hameed, A., Abbas, F., \& Ahmad, M. S. A. (2014). Glycine betaine-induced lead toxicity tolerance related to elevated photosynthesis, antioxidant enzymes suppressed lead uptake and oxidative stress in cotton. Turkish Journal of Botany, 38(2), 281-292. doi: 10.3906/bot-1304-65

Bhatti, K. H., Anwar, S., Nawaz, K., Hussain, K., Siddiqi, E. H., Sharif, R. U.,... Khalid, A. (2013). Effect of exogenous application of glycinebetaine on wheat (Triticum aestivum L.) under heavy metal stress. Middle-East Journal of Science Research, 14(1), 130-137. doi: 10.5829/idosi.mejsr. 2013.14.1.19550

Blunden, G., Jenkins, T., \& Liu, Y. (1996). Enhanced leaf chlorophyll levels in plants treated with seaweed extract. Journal of Applied Phycology, 8(6), 535-543. doi: 10.1007/BF02186333
Cairns, A., Watson, M., Creanor, S., \& Foye, R. (2002). The $\mathrm{pH}$ and titratable acidity of a range of diluting drinks and their potential effect on dental erosion. Journal of Dentist, 30(7-8), 313-317. doi: 10.1016/ S0300-5712(02)00044-1

Chen, T. H., \& Murata, N. (2008). Glycinebetaine: an effective protectant against abiotic stress in plants. Trends in Plant Science, 13(9), 499-505. doi: 10.1016/j. tplants.2008.06.007

Chen, T. H., \& Murata, N. (2011). Glycinebetaine protects plants against abiotic stress: mechanisms and biotechnological applications. Plant, Cell \& Environment, 34(1), 1-20. doi: 10.1111/j.1365-3040.20 10.02232.x

Cuin, T. A., \& Shabala, S. (2007). Compatible solutes reduce ROS induced potassium efflux in Arabidopsis roots. Plant, Cell \& Environment, 30(7), 875-885. doi: 10. 1111/j.1365-3040.2007.01674.x

Duman, F., Aksoy, A., Aydin, Z., \& Temizgul, R. (2011). Effects of exogenous glycinebetaine and trehalose on cadmium accumulation and biological responses of an aquatic plant (Lemna gibba L.). Water, Air, \& Soil Pollution, 217(1), 545-556. doi: 10.1007/s11270-010-0608-5

Farooq, M., Aziz, T., Hussain, M., Rehman, H., Jabran, K., \& Khan, M. B. (2008). Glycinebetaine improves chilling tolerance in hybrid maize. Journal of Agronomy and Crop Science, 194(2), 152-160. doi: 10.11 11/j.1439-037X.2008.00295.x

Farooq, M., Wahid, A., Ito, O., Lee, D. J., \& Siddique, K. H. M. (2009). Advances in drought resistance of rice. Critical Reviews in Plant Science, 28(4), 199-217. doi: 10.1080/07352680902952173 
Ferrandino, A., \& Lovisolo, C. (2013). Abiotic stress effects on grapevine (Vitis vinifera L.): focus on abscisicacid-mediated consequences on secondary metabolism and berry quality. Environmental and Experimental Botany, 103(1), 138-147. doi: 10.1016/j.envexpbot.2013.10.012

Gadallah, M. M. A. (1999). Effects of proline and glycinebetaine on Vicia faba responses to salt stress. Biologia Plantarum, 42(2), 249257. doi: 10.1023/A:1002164719609

Giri, J. (2011). Glycinebetaine and abiotic stress tolerance in plants. Plant Signaling \& Behavior, 6(11), 1746-1751. doi: 10. 4161/psb.6.11.17801

Grimplet, J., Wheatley, M. D., Jouira, H. B., Deluc, L. G., Cramer, G. R., \& Cushman, J. C. (2009). Proteomic and selected metabolite analysis of grape berry tissues under well watered and water deficit stress conditions. Proteomics, 9(9), 25032528. doi: 10.1002/pmic.200800158

Habib, N., Ashraf, M., Ali, Q., \& Perveen, R. (2012). Response of salt stressed okra (Abelmoschus esculentus Moench) plants to foliar-applied glycine betaine and glycine betaine containing sugarbeet extract. South African Journal of Botany, 83(1), 151-158. doi: 10.1016/j. sajb.2012.08.005

Hussain, M., Malik, M. A., Farooq, M., Ashraf, M. Y., \& Cheema, M. A. (2008). Improving drought tolerance by exogenous application of glycinebetaine and salicylic acid in sunflower. Journal of Agronomy and Crop Science, 194(3), 193-199. doi: 10.1111/j.1439-037X.2008.00305.x

Khan, S. (2019). Climate classification of Pakistan. International Journal of
Economic and Environmental Geology, 10(2), 60-71. Retrived from https:// scholar.google.com/scholar?hl=en\&as $\mathrm{sdt}=0 \% 2 \mathrm{C} 5 \& \mathrm{q}=$ Climate + classification $+\mathrm{O}$ $\mathrm{f}+$ Pakistan\&btnG $=$

Kumar, V., Shriram, V., Hoque, T. S., Hasan, M. M., Burritt, D. J., \& Hossain, M. A. (2017). Glycinebetaine-mediated abiotic oxidative-stress tolerance in plants: physiological and biochemical mechanisms. Stress Signaling in Plants: Genomics and Proteomics Perspective, 2(2), 111-133. doi: 10.1007/978-3-31942183-4_5

Li, R.-H., Guo, P.-G., Michael, B., Stefania, G., \& Salvatore, C. (2006). Evaluation of chlorophyll content and fluorescence parameters as indicators of drought tolerance in barley. Agricultral Sciences in China, 5(10), 751-757. doi: 10.1016/ S1671-2927(06)60120-X

Long, S. P., \& Bernacchi, C. (2003). Gas exchange measurements, what can they tell us about the underlying limitations to photosynthesis? Procedures and sources of error. Journal of Experimental Botany, 54(392), 2393-2401. doi: 10.1093/jxb/erg 262

Mahouachi, J., Argamasilla, R., \& GómezCadenas, A. (2012). Influence of exogenous glycine betaine and abscisic acid on papaya in responses to waterdeficit stress. Journal of Plant Growth Regulation, 31(1), 1-10. doi: 10.1007/ s00344-011-9214-z

Mäkelä, P., Munns, R., Colmer, T. D., Condon, A. G., \& Peltonen-Sainio, P. (1998). Effect of foliar applications of glycinebetaine on stomatal conductance, abscisic acid and 
solute concentrations in leaves of saltor drought-stressed tomato. Functional Plant Biology, 25(6), 655-663. doi: 10.1071/PP9 8024

Malik, S., \& Ashraf, M. (2012). Exogenous application of ascorbic acid stimulates growth and photosynthesis of wheat (Triticum aestivum L.) under drought. Soil and Environment, 31(1), 72-77.

Manivannan, P., Rabert, G. A., Rajasekar, M., \& Somasundaram, R. (2015). Drought stress induced modification on growth and Pigments composition in different genotypes of (Helianthus annuus L.). Current Botany, 5(1), 7-13. Retrieved from http://scienceflora.org/journals/index. php/jp/

Mickelbart, M. V., Chapman, P., \& CollierChristian, L. (2006). Endogenous levels and exogenous application of glycinebetaine to grapevines. Scientia Horticulturae, 111(1), 7-16. doi: 10.1016/j. scienta.2006.07.031

O'Neal, M. E., Landis, D. A., \& Isaacs, R. (2002). An inexpensive, accurate method for measuring leaf area and defoliation through digital image analysis. Journal of Economic Entomology, 95(6), 1190-1194. doi: 10.1603/0022-0493-95.6.1190

Park, E. J., Jeknic, Z., \& Chen, T. H. (2006). Exogenous application of glycinebetaine increases chilling tolerance in tomato plants. Plant and Cell Physiology, 47(6), 706-714. doi: 10.1093/pcp/pcj041

Pireivatlou, A. S., Aliyev, R., Hajieva, S., Javadova, S., \& Akparov, Z. (2008). Structural changes of the photosynthetic apparatus; morphological and cultivation responses in different wheat genotypes under drought stress condition. Abstract of the International Wheat Genetics Symposium, Bako, Republic of Azerbaijan, 11.

Rehman, K. U., Haq, F. U., Amin, J., Shah, A., Khan, U., \& Nabi, G. (2018). Grapes characterization of different varieties in the central zone of peshawar kpk. International Journal of Environmental Sciences \& Natural Resources, 9(1), 26-29. doi: 10.19080/IJESNR.2018.08.555754

Rezaei, M. A., Jokar, I., Ghorbanli, M., Kaviani, B., \& Kharabian-Masouleh, A. (2012). Morpho-physiological improving effects of exogenous glycine betaine on tomato (Lycopersicum esculentum Mill.) cv. PS under drought stress conditions. Plant Omics Journal, 5(2), 79-86. doi: 10.3316/ informit.183039918874309

Saleem, B. A., Malik, A. U., \& Farooq, M. (2007). Effect of exogenous growth regulators application on June fruit drop and fruit quality in Citrus sinensis cv. Blood red. Pakistan. Journal of Agricultural Sciences, 44(2), 1-6.

Shahbaz, M., Masood, Y., Perveen, S., \& Ashraf, M. (2012). Is foliar-applied glycinebetaine effective in mitigating the adverse effects of drought stress on wheat (Triticum aestivum L.)? Journal of Applied Botany and Food Quality, 84(2), 192-199.

Sorwong, A., \& Sakhonwasee, S. (2015). Foliar application of glycine betaine mitigates the effect of heat stress in three marigold (Tagetes erecta) cultivars. The Horticulture Journal, 84(2), 161-171. doi: 10.2503/hortj.MI-038 
Steel, R. G. D., Torrie, J. H., \& Dickey, D. A. (1997). Principles and procedures of statistics. A biometrical approach (3nd ed.). Singapore City, Singapore: McGraw Hill Book.

Yang, W. J., Rich, P. J., Aztell, J. D., Wood, K. V., \& Bonham, C. C. (2003). Genotypic variation for glycinebetaine in sorghum. Crop Science, 43(1), 162-169. doi: 10.2135/ cropsci2003.1620
Zhang, Y., Mechlin, T., \& Dami, I. (2011). Foliar application of abscisic acid induces dormancy responses in greenhousegrown grapevines. Horticulture Science, 46(9), 1271-1277. doi: 10.21273/HORT SCI.46.9.1271a 